\title{
Microscopic extraovarian sex cord proliferations: an undescribed phenomenon
}

\author{
W Glenn McCluggage, ${ }^{1}$ Colin J R Stewart, ${ }^{2}$ Jean Iacobelli, ${ }^{2}$ Anita Soma, ${ }^{2}$ Kathleen R Cho, ${ }^{3}$ \\ Mark K Heatley, ${ }^{4}$ Adam Boyde ${ }^{5}$ \& Blaise A Clarke ${ }^{6}$ \\ ${ }^{1}$ Department of Pathology, Belfast Health and Social Care Trust, Belfast, UK, ${ }^{2}$ Department of Pathology, King Edward \\ Memorial Hospital, Perth, WA, Australia, ${ }^{3}$ Department of Pathology, University of Michigan Medical School, Ann \\ Arbor, MI, USA, ${ }^{4}$ Department of Pathology, St James's Hospital, Leeds, UK, ${ }^{5}$ Department of Pathology, University of \\ Hospital, Cardiff, UK, and ${ }^{6}$ Department of Laboratory Medicine and Pathobiology, University Health Network, \\ University of Toronto, Toronto, ON, Canada
}

Date of submission 15 September 2014

Published online Article Accepted 12 October 2014

\begin{abstract}
McCluggage W G, Stewart C J R, Iacobelli J, Soma A, Cho K R, Heatley M K, Boyde A \& Clarke B A (2015) Histopathology 66, 555-564. DOI: 10.1111/his.12580
\end{abstract}

\section{Microscopic extraovarian sex cord proliferations: an undescribed phenomenon}

Aims: To report a previously undescribed phenomenon of incidentally detected microscopic proliferations of sex cord cells, often mimicking adult granulosa cell tumour or sex cord tumour with annular tubules, in extraovarian locations.

Methods and results: The six cases were in patients aged 23-58 years. The proliferations were located in the fallopian tube in three cases, and in paraovarian connective tissues, the pelvic side wall, and appendiceal serosa (one case each). Microscopically, they were typically composed of well-demarcated nests of regular cells with round/ovoid vesicular nuclei, some containing grooves. Microfollicular and/or cribriform arrangements were present in three cases. In five cases, the sex cord lineage was confirmed by positive staining with inhibin and/or calretinin and other sex cord markers. FOXL2 mutation analysis was performed in one case, but was inconclusive. Bilateral oophorectomies and bilateral cystectomies were performed in three cases and one case respectively; there was no sex cord-stromal neoplasm in the removed ovaries. In the two cases in which the ovaries were not removed, imaging showed no suspicious features. Follow-up in four cases (11 months-6 years) has been uneventful. Conclusions: The pathogenesis of these microscopic extraovarian sex cord proliferations is unknown, but they may represent non-neoplastic proliferations of embryonic remnants.

Keywords: adult granulosa cell tumour, extraovarian tissues, fallopian tube, immunohistochemistry, ovary, sex cord

\section{Introduction}

Ovarian sex cord-stromal tumours constitute a heterogeneous group of neoplasms, the most common malignant variant being adult-type granulosa cell tumour (AGCT). There have been rare reports of primary extraovarian AGCT, most

Address for correspondence: W G McCluggage, Department of Pathology, Royal Group of Hospitals Trust, Grosvenor Road, Belfast BT12 6BA, UK. e-mail: glenn.mccluggage@belfasttrust.hscni.net commonly in the broad ligament. ${ }^{1,2}$ In this study, we report a series of cases in which incidental microscopic collections of sex cord cells, most of which closely mimicked AGCT or sex cord tumour with annular tubules (SCTAT), were identified in extraovarian tissues in the absence of an ovarian sex cord neoplasm. We discuss the differential diagnosis, and speculate upon the pathogenesis of this rare phenomenon, which, so far as we are aware, has not been previously described in the literature. 


\section{Materials and methods}

The cases were derived from the in-house cases or the consultation practice of the authors. All of the haematoxylin and eosin-stained sections were reviewed. Immunohistochemistry was performed in most cases at the time of initial reporting. FOXL2 mutation analysis was performed on case 2, as previously described. $^{3}$ Follow-up was obtained by liaison with the referring pathologists or other clinicians involved in patient management, or inspection of the clinical notes. This article is a retrospective description of a case series, so ethics approval was not required.

\section{Results}

Clinicopathological details of the six cases are presented in Table 1. The patients ranged in age from
23 to 58 years; two patients were postmenopausal. Three patients underwent hysterectomy and bilateral salpingo-oophorectomy, one bilateral salpingo-oophorectomy, one bilateral cystectomy and pelvic side wall biopsy, and one appendicectomy. Follow-up is available for four patients, ranging from 11 months to 6 years, and has been uneventful, with no subsequent tumour development. Cases 2 and 3 are recent with no significant follow-up available. The ovaries were removed from neither patient, but clinical and detailed radiological examination, including computed tomography and ultrasound scans, showed no ovarian or pelvic masses.

In three cases, the sex cord proliferation involved the fallopian tube (fimbria in cases 1 and 2; isthmus in case 6) (right tube in one case; laterality unknown in two cases). In one case each, the proliferations involved the paraovarian connective

Table 1. Clinicopathological features of the cases in this study

\begin{tabular}{|c|c|c|c|c|c|c|}
\hline Case & $\begin{array}{l}\text { Age } \\
\text { (years) }\end{array}$ & $\begin{array}{l}\text { Indication for } \\
\text { surgery }\end{array}$ & $\begin{array}{l}\text { Operative } \\
\text { procedure }\end{array}$ & $\begin{array}{l}\text { Location of sex } \\
\text { cord proliferations }\end{array}$ & Immunohistochemistry & Follow-up \\
\hline 1 & 58 & Unknown & $\begin{array}{l}\text { Bilateral salpingo- } \\
\text { oophorectomy }\end{array}$ & $\begin{array}{l}\text { Fallopian tube } \\
\text { fimbria }\end{array}$ & $\begin{array}{l}\text { Positive for inhibin and } \\
\text { calretinin; negative for } \\
\text { chromogranin and p63 }\end{array}$ & 48 months \\
\hline 2 & 39 & $\begin{array}{l}\text { Uterine fibroids } \\
\text { and menorrhagia }\end{array}$ & $\begin{array}{l}\text { Hysterectomy and } \\
\text { bilateral salpingectomy }\end{array}$ & $\begin{array}{l}\text { Fallopian tube } \\
\text { fimbria }\end{array}$ & $\begin{array}{l}\text { Positive for inhibin and } \\
\text { calretinin }\end{array}$ & Recent case \\
\hline 3 & 48 & $\begin{array}{l}\text { Presumed acute } \\
\text { appendicitis }\end{array}$ & Appendicectomy & $\begin{array}{l}\text { Appendiceal } \\
\text { serosa }\end{array}$ & $\begin{array}{l}\text { Positive for inhibin, } \\
\text { calretinin, WT1, and } \\
\text { MNF116; negative for } \\
\text { EMA and CD56 }\end{array}$ & Recent case \\
\hline 4 & 23 & $\begin{array}{l}\text { Ovarian cysts } \\
\text { and ? pelvic } \\
\text { endometriosis }\end{array}$ & $\begin{array}{l}\text { Bilateral cystectomies } \\
\text { and pelvic side wall } \\
\text { biopsy }\end{array}$ & $\begin{array}{l}\text { Right pelvic } \\
\text { side wall }\end{array}$ & $\begin{array}{l}\text { Diffusely positive for } \\
\text { inhibin, calretinin, SF1, } \\
\text { WT1, ER, PR, and AE1/3; } \\
\text { focally positive for CD56 } \\
\text { and CD99; negative for } \\
\text { p63, chromogranin, and } \\
\text { synaptophysin }\end{array}$ & 11 months \\
\hline 5 & 58 & $\begin{array}{l}\text { Endometrial } \\
\text { carcinoma }\end{array}$ & $\begin{array}{l}\text { Hysterectomy and } \\
\text { bilateral salpingo- } \\
\text { oophorectomy }\end{array}$ & $\begin{array}{l}\text { Para-ovarian } \\
\text { connective tissues } \\
\text { and ovarian } \\
\text { capsular adhesions }\end{array}$ & $\begin{array}{l}\text { Diffusely positive for } \\
\text { inhibin, SF1, WT1, ER, } \\
\text { PR, and AE1/3; focally } \\
\text { positive for calretinin, } \\
\text { CD56, and CD99; negative } \\
\text { for p63, chromogranin, } \\
\text { and synaptophysin }\end{array}$ & 2 years \\
\hline 6 & 39 & Uterine fibroids & $\begin{array}{l}\text { Hysterectomy and } \\
\text { bilateral salpingo- } \\
\text { oophorectomy }\end{array}$ & Fallopian tube & None performed & 6 years \\
\hline
\end{tabular}

EMA, Epithelial membrane antigen; ER, Oestrogen receptor; PR, Progesterone receptor; SF1, Steroidogenic factor 1; WT1, Wilms tumour 1. 
tissues, the right pelvic side wall, and the appendiceal serosa.

Of the three cases involving the tube, the two that involved the fimbriae (cases 1 and 2) had a similar morphological appearance. In one case, multiple nests and in the other two nests of cells were located within the lamina propria just beneath the surface epithelium. The individual nests were small (always $<1 \mathrm{~mm}$ ), round, and well demarcated, and were composed of regular cells with round to ovoid vesicular nuclei and a moderate amount of cytoplasm. Some of the nuclei were grooved. There was little or no nuclear pleomorphism, and mitotic figures were not identified. Microfollicular arrangements were present, and many of the nests had a cribriform appearance, with punched-out spaces containing eosinophilic hyaline material. In case 1 , a single nest with a similar morphology was present within the ovarian parenchyma.

The third fallopian tube lesion (case 6) was located in the isthmus, and involved the lamina propria just deep to the surface epithelium. It was larger than the other lesions, measuring $3.75 \mathrm{~mm}$ in maximum dimension, and extended into the muscle wall of the tube. It was composed of multiple interconnecting nests of cells; in contrast to the other cases, the nests had an irregular outline. Occasional slit-like spaces and a focal pseudopapillary architecture were present. No follicular arrangements were present. The nuclei were ovoid to spindled and vesicular, with no pleomorphism or mitotic activity. The cytoplasm was scant and indiscernible.

In one case (case 3), there was a single small $(<1 \mathrm{~mm})$ well-circumscribed nest of cells on the appendiceal serosa (the appendix showed features of acute appendicitis). The nest was 'solid', with no follicles or luminal spaces. The cells had round vesicular nuclei, some containing grooves, and a moderate amount of cytoplasm. There was little nuclear pleomorphism and no mitotic activity.

In case 4 , the sex cord proliferation was present in a right pelvic side wall biopsy within fibrovascular adhesions that contained occasional endosalpingiotic glands. There were several small $(<1 \mathrm{~mm})$ well-circumscribed nests of cells, with no follicles or luminal spaces. The cells had round to ovoid vesicular nuclei and a moderate amount of cytoplasm. Occasional nuclear grooves were present. There was no nuclear atypia or mitotic activity.

In case 5, the sex cord proliferation was present in paraovarian connective tissues. There were multiple small $(<1 \mathrm{~mm})$ well-circumscribed nests of cells with occasional microfollicular spaces and scant eosino- philic hyaline material. The cells had round to ovoid vesicular nuclei and a moderate amount of cytoplasm. Occasional nuclear grooves were present. There was no nuclear atypia or mitotic activity. In this case, similar nests of cells involved ovarian capsular adhesions.

Morphologically, the proliferations in cases 1 and 2 bore a resemblance to both AGCT and SCTAT. In cases 3, 4, and 5, the morphology was reminiscent of AGCT.

All ovaries and cystectomy specimens were submitted in their entirety for histological examination. No sex cord lesions were identified, except for a single focus in the parenchyma in case 1 and several nests in capsular adhesions in case 5, as already described.

The immunohistochemical results are presented in Table 1. All five cases tested were positive for inhibin and calretinin. Other positive markers were Wilms tumour 1 (WT1) (3/3), steroidogenic factor 1 (SF1) $(2 / 2)$, oestrogen receptor $(2 / 2)$, progesterone receptor $(2 / 2)$, broad-spectrum cytokeratins (3/3; punctate cytoplasmic staining), CD56 (2/3), and CD99 (2/2). Epithelial membrane antigen (EMA), chromogranin, synaptophysin and p63 were negative in all cases tested. Immunohistochemistry was not performed on case 6 , because the lesion disappeared following levelling of the block.

The results of FOXL2 mutation testing in case 2 were inconclusive, owing to low concentrations of DNA, despite being performed on two occasions. Figures 1-6 are representative images of cases 1-6, respectively.

Other pathological findings included uterine leiomyomata in case 2, acute appendicitis in case 3, ovarian follicular cysts in case 4 , a grade 1 stage $1 \mathrm{~A}$ endometrioid adenocarcinoma of the uterine corpus and peritoneal endometriosis in case 5, and uterine leiomyomas, ovarian endometriosis and endometriosis surrounding the fallopian tube in case 6 .

\section{Discussion}

We have described a series of unusual incidentally detected microscopic proliferations of sex cord cells in extraovarian locations. This phenomenon has not been reported in the literature, but, interestingly, is illustrated in one major gynaecological pathology textbook. ${ }^{4}$ In the four cases in which oophorectomies or ovarian cystectomies were performed, there were no similar sex cord elements in two of the cases. In the remaining two cases, a single similar microscopic nest of sex cord cells was present in the ovarian stroma in one case, and several nests were present in 


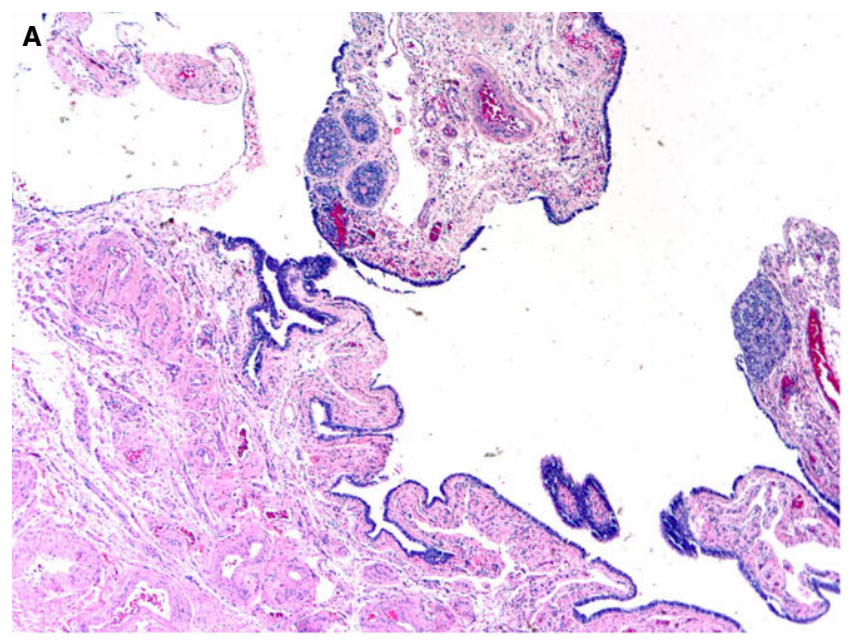

B
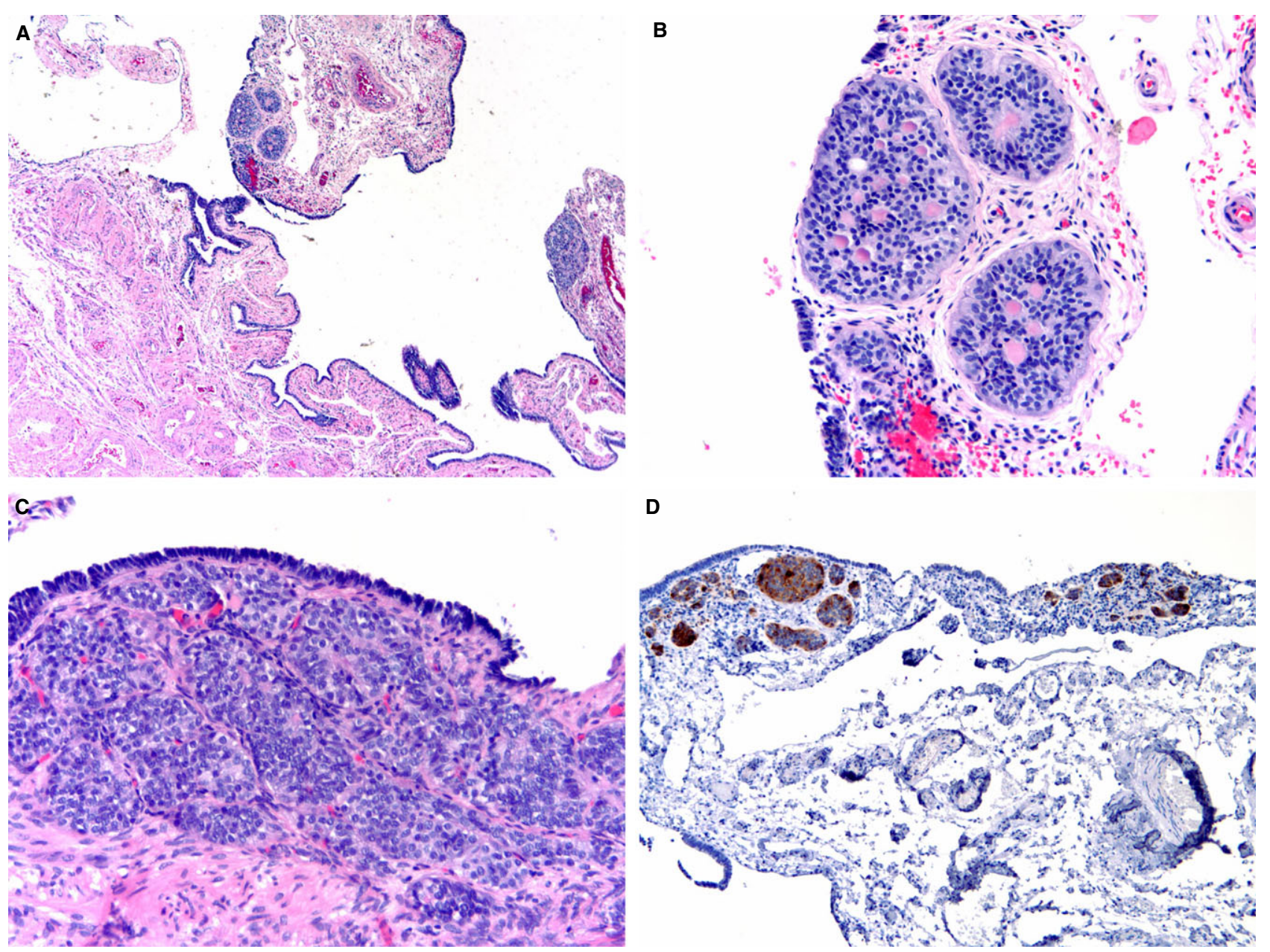

D

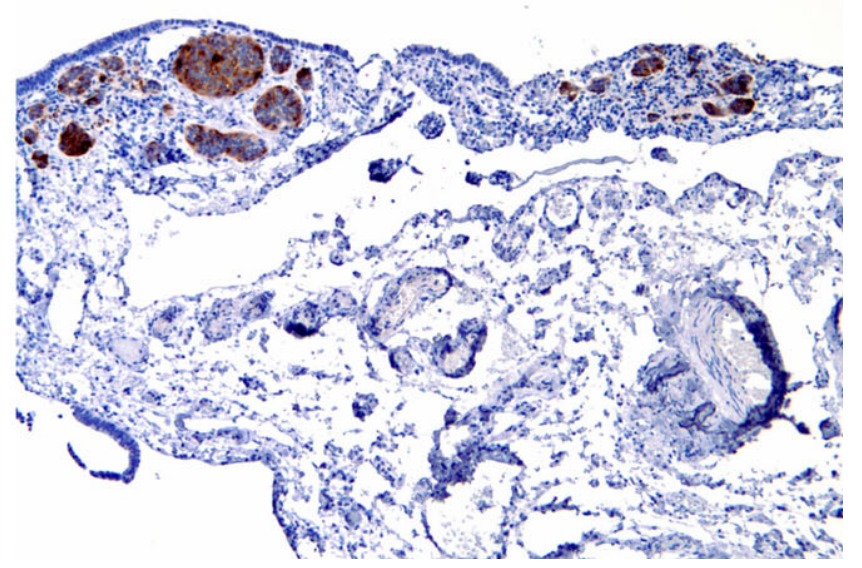

Figure 1. Case 1. Multiple small nests of sex cord cells are present in the lamina propria of the fallopian tube fimbria (A). At higher power, the nests are well demarcated and composed of regular cells surrounding punched-out spaces containing eosinophilic hyaline material (B). Some of the nests are more solid, with ill-defined microfollicles (C). The cell nests are diffusely positive for inhibin (D).

capsular adhesions in the other case. In two cases, the ovaries were not removed, but there was no clinical or radiological evidence of an ovarian mass. The sex cord lineage was proven by immunohistochemistry in all cases except one by positive staining for inhibin and/or calretinin, the two most commonly utilized sex cord-stromal markers. The other immunohistochemical findings, e.g. nuclear staining with WT1 and SF1, negative EMA, and punctate cytoplasmic staining with broad-spectrum cytokeratins, were also in keeping with a sex cord lineage. Although we were not able to perform confirmatory immunohistochemistry in case 6 , we feel that the morphological features were in keeping with a sex cord proliferation.

Morphologically, the sex cord proliferations resembled AGCT and/or SCTAT. The nuclear features usually resembled an AGCT with bland vesicular nuclei, some containing grooves. The nested and microfollicular architectural patterns were also consistent with AGCT. In two of the cases, there was a cribriform architecture with punched-out spaces containing eosinophilic hyaline material, features resembling a SCTAT. The latter neoplasm, or similar microscopic proliferations, may occur in the ovaries in patients with Peutz Jegher syndrome; none of the patients in our series had a known history of this syndrome.

There are a number of possible explanations for the pathogenesis of these extraovarian microscopic proliferations of sex cord cells. One possibility is that they represent small extraovarian AGCTs, SCTATs, or other types of sex cord-stromal tumour, and, as stated, AGCTs and other sex cord-stromal neoplasms, such as tumours in the fibroma-thecoma group and steroid cell tumours, have rarely been reported at extraovarian locations, where they have been postulated to arise from accessory ovarian tissue. ${ }^{1,2,5-9}$ 

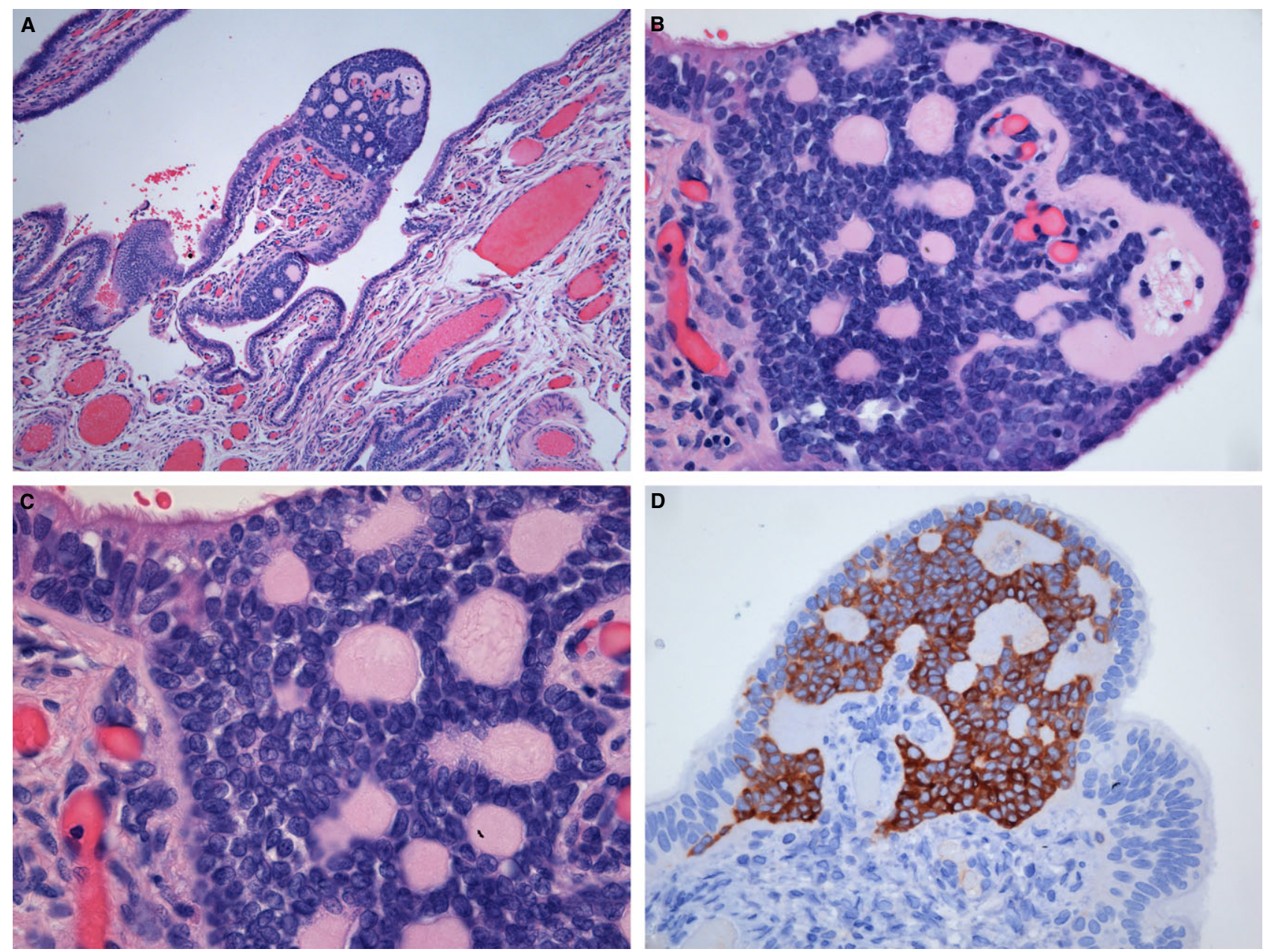

Figure 2. Case 2. Small nests of sex cord cells are present in the lamina propria of the fallopian tube fimbria (A). At higher power, the nests are well demarcated and composed of regular cells with punched-out spaces containing eosinophilic hyaline material (B). The nuclear features are bland, and occasional nuclei contain grooves (C). The cell nests are diffusely positive for inhibin (D).

However, all of the extraovarian AGCTs were reported in the older literature, and it is possible that some were, in fact, histological mimics, such as female adnexal tumour of Wolffian origin. Although it is possible that the lesions presented herein represent microscopic extraovarian AGCTs or SCTATs, we feel that it is unlikely, given the extreme rarity of these neoplasms in extraovarian locations; we are aware of only two case reports of extraovarian AGCTs, and are not aware of an extraovarian SCTAT having been reported. Recently, a somatic missence mutation in codon $\mathrm{C} 134 \mathrm{~W}(402 \mathrm{C} \rightarrow \mathrm{G})$ of the FOXL2 gene, which encodes a transcription factor that is known to be critical for granulosa cell development, has been demonstrated in at least $90 \%$ of ovarian AGCTs and only extremely rarely in other sex cordstromal tumours. ${ }^{10-12}$ FOXL2 mutation is emerging as an extremely sensitive and specific molecular marker of AGCT. We undertook FOXL2 mutation analysis in one of our cases (case 2), and the results were inconclusive. It has been postulated that CD56 is of value in the distinction between a sex cordstromal tumour and non-neoplastic granulosa cells. $^{13,14}$ Most ovarian sex cord-stromal tumours, including AGCT and SCTAT, are CD56-positive, whereas non-neoplastic granulosa cells are negative. $^{13,14}$ One of our cases was CD56-negative and two were focally positive and, although only three cases were stained, we feel that this marker is of limited value in the distinction between a sex cord-stromal tumour and non-neoplastic granulosa cells.

In one case, there were ovarian capsular adhesions containing similar nests of cells to the extraovarian sex cord proliferation, and in another the sex cord proliferation was present in an adhesion from the pelvic side wall. The proliferation on the serosa of the 

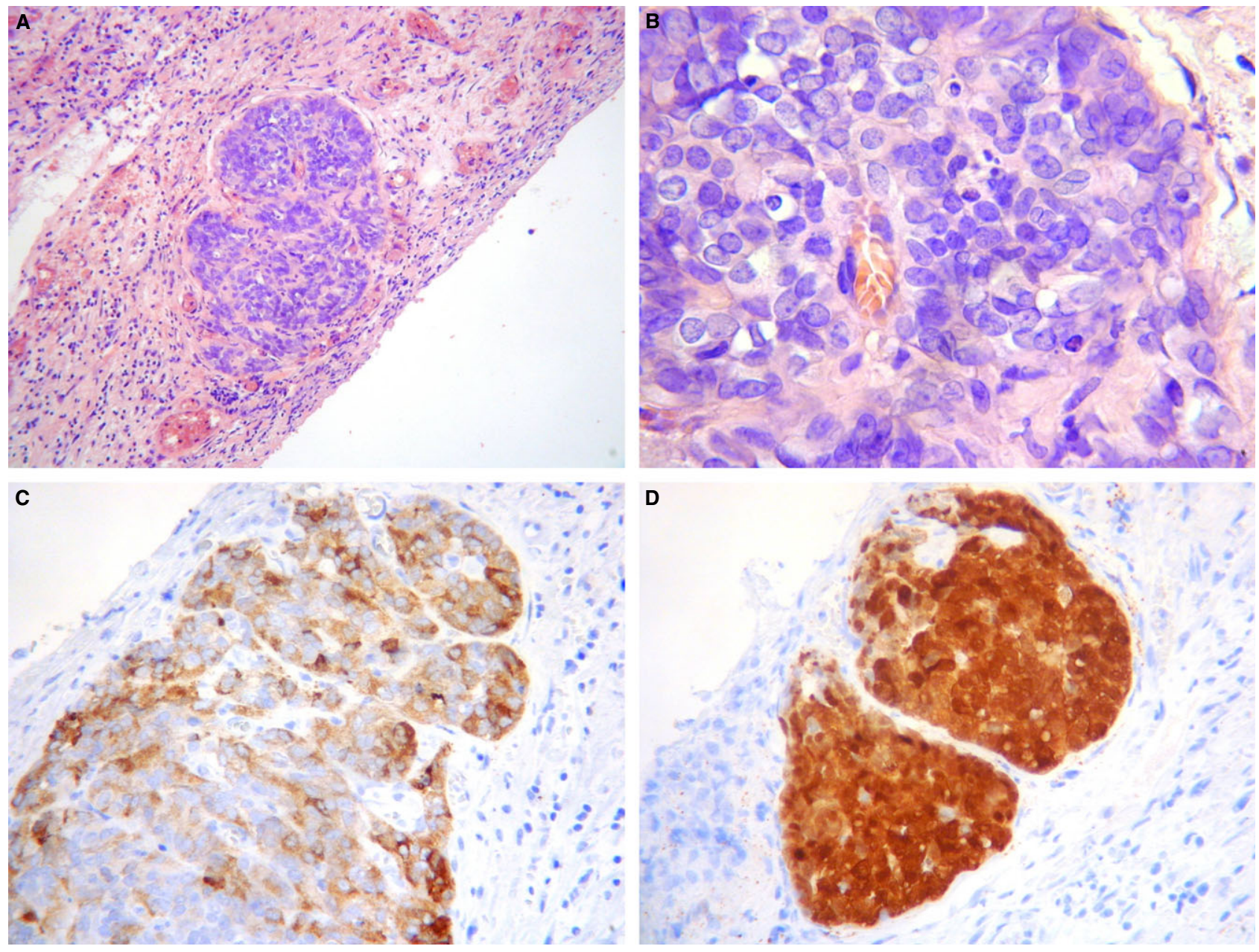

Figure 3. Case 3. A single well-demarcated nest of sex cord cells is present on the appendiceal serosa (A). The nuclear features are bland, and occasional nuclei contain grooves (B). The cell nests are diffusely positive for inhibin (C) and calretinin (D).

appendix was associated with acute appendicitis. It is theoretically possible that, in these cases, the sex cord proliferations formed secondary to adhesions or inflammation via a metaplastic process; however, again we consider this to be unlikely.

Another possibility is that the extraovarian sex cord cells represent embryonic rests with an abnormal location owing to aberrant migration, resulting in a form of heterotopia. This is perhaps the most likely explanation for the sex cord proliferations in the cases reported here. Heterotopic hilus or Leydig cells have also been reported at extraovarian locations, including the fallopian tube. ${ }^{15}$ Adrenal rests are also occasionally seen, and there has been a single report of ectopic pancreatic tissue. ${ }^{16}$

Some parallels can be drawn between the microscopic proliferations resembling AGCT or SCTAT that we have reported and microscopic proliferations indistinguishable from AGCT (AGCT-like proliferations), which are rarely seen in the stroma of ovarian epithelial lesions, such as mucinous and serous cystadenomas and endometriotic cysts. ${ }^{17}$ One of us (W.G.M.) co-authored a series of such cases, most of which lacked FOXL2 mutation and which probably represent non-neoplastic ovarian stromal proliferations. ${ }^{17}$ Similar microscopic ovarian proliferations mimicking AGCT may be seen in pregnancy. ${ }^{18}$ These lesions are usually multiple and are related to ovarian follicles, and it is speculated that they represent an unusual physiological response to the elevated chorionic gonadotropin level of pregnancy rather than early stages of neoplasia. None of the patients in our series was pregnant.

One differential diagnosis of the lesions described here that is worthy of consideration is the phenomenon whereby granulosa cells are displaced from developing ovarian follicles into ovarian tissue spaces and true vascular spaces and also occasionally into 

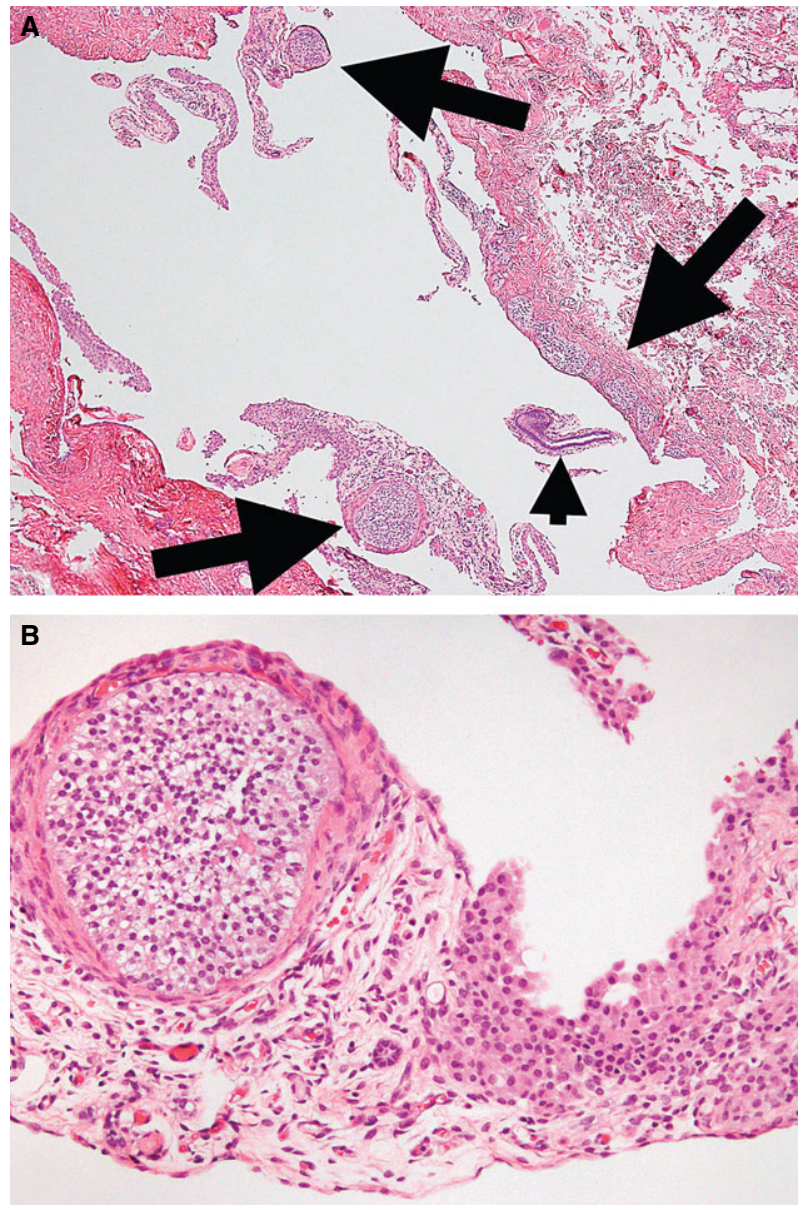

Figure 4. Case 4. Pelvic side wall biopsy. At scanning magnification, there are multiple well-demarcated nests of sex cord cells (arrows) abutting the serosal surface; a detached endosalpingiotic gland (short arrow) is present (A). At higher magnification, a sex cord-like aggregate is composed of cells with uniform small nuclei and eosinophilic to clear cytoplasm (B).

extraovarian tissues, including the fallopian tube. ${ }^{19-22}$ These displaced granulosa cells typically have hyperchromatic nuclei, which are often crushed and show moulding, and potentially mimic small-cell carcinoma (Figure 7). When the granulosa cells are luteinized, the displaced cells may simulate non-small-cell carcinoma or other neoplasms. Normal granulosa cells may be mitotically active, and this may further heighten the suspicion of malignancy. This displacement of granulosa cells is most likely to be an artefact of surgery or specimen dissection, although it could also be secondary to ovulation. ${ }^{19-22}$ The sex cord proliferations reported here differ from such displaced granulosa cells in that the nuclei in the former are usually vesicular rather than hyperchromatic and do not have a crushed appearance. Moreover, displaced granulosa cells do not show the various architectural arrangements seen in some of our cases. Displaced granulosa cells only occur in patients in the reproductive years; two patients in our study were postmenopausal. Differences between the extraovarian sex cord proliferations reported here and displaced granulosa cells are presented in Table 2. One of us (W Glenn McCluggage) has seen several cases of displaced granulosa cells within the fallopian tube $\mathrm{e}^{20}$ (W Glenn McCluggage, unpublished observations), and this may be a diagnostic consideration, especially with tubal sex cord proliferations. A recent report has described a similar case of displaced granulosa cells within the fallopian tube, but we feel, on review of the photomicrographs, that this may represent a sex cord proliferation similar to the cases reported here rather than displaced granulosa cells; ${ }^{22}$ in particular, it bears a close morphological resemblance to case 6 in our series.

The differential diagnosis of extraovarian sex cord proliferations might also potentially include several other neoplastic and non-neoplastic lesions, such as carcinoid tumour, mesothelial proliferations, Walthard's rests, and adrenal rests. If considered, these are usually easily excluded by morphology supplemented by immunohistochemistry if needed, as discussed in the following paragraphs.

In one of the cases reported here, the sex cord proliferation involved the appendiceal serosa, a site where carcinoid tumours may be identified. Metastatic carcinoid tumour might also be a potential diagnostic consideration, whatever the location. The nuclei are usually more hyperchromatic in carcinoid tumour, with 'salt and pepper' chromatin, in contrast to the more vesicular nuclei in sex cord proliferations. Immunohistochemistry is useful in that carcinoids are usually positive for chromogranin and synaptophysin and negative for inhibin and calretinin, whereas sex cord proliferations show the converse immunophenotype. Both may be CD56-positive. Mesothelial proliferations might also enter into the differential diagnosis. Both mesothelial and sex cord proliferations are commonly calretinin-positive and WT1-positive, but mesothelial proliferations are inhibin-negative. Walthard's rests (nests of transitional epithelium) are commonly seen as incidental microscopic findings in pelvic soft tissues, especially around the fallopian tube and ovary. In common with sex cord proliferations, they often contain nuclear grooves, but they do not show the characteristic architectural patterns seen in some of the sex cord proliferations. Walthard's rests are inhibin-negative, calretinin-negative, and p63-positive. Adrenal rests are occasionally seen as an incidental finding in paraovarian and paratubal tissues. These can have a 

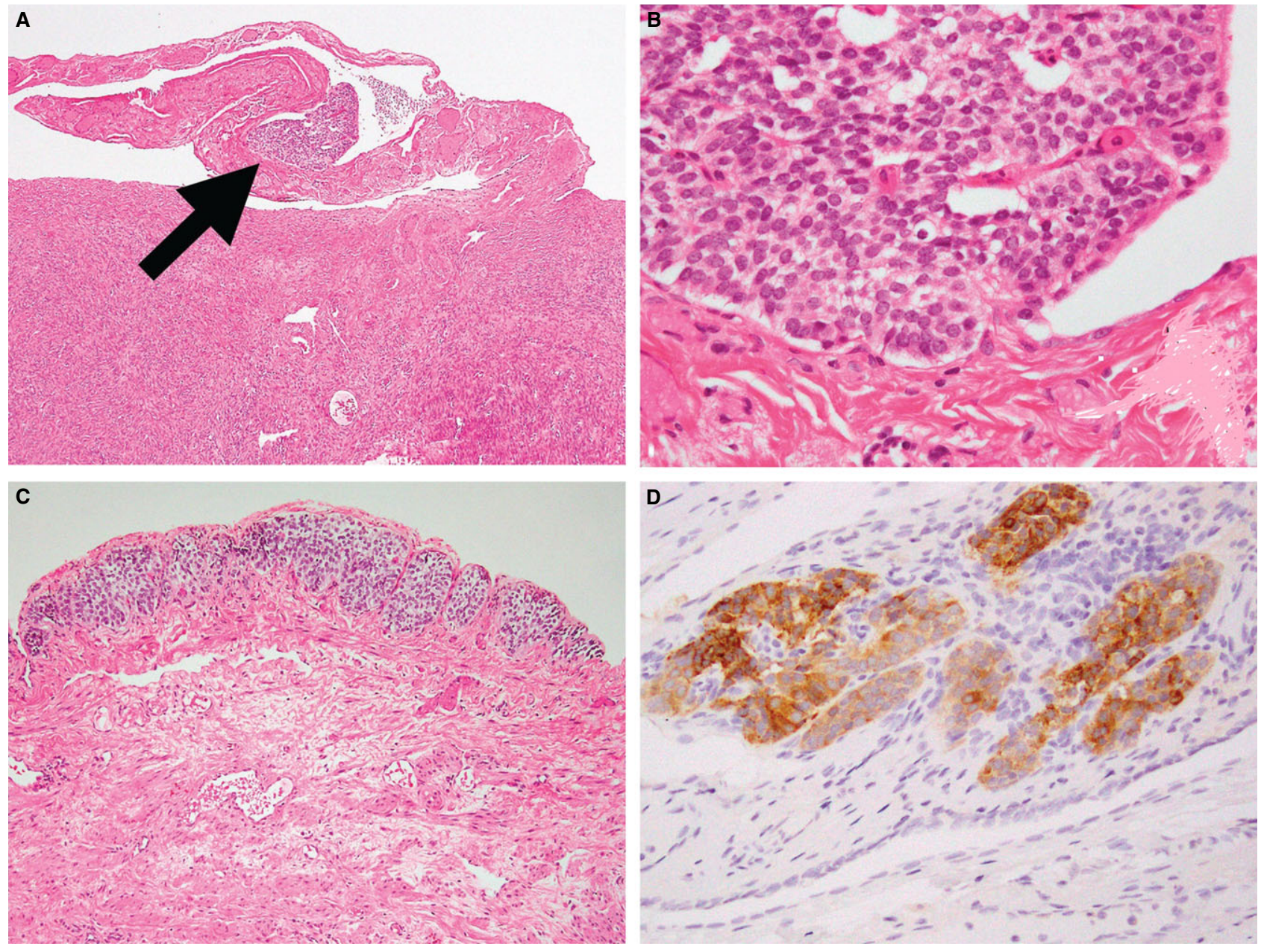

Figure 5. Case 5. Scanning magnification of ovarian cortex shows a nest of sex cord-like cells (arrow) within surface capsular fibrous adhesions (A). Higher magnification demonstrates bland cytological features and occasional follicle-like spaces (B). Clusters of sex cord-like cells are present within the paraovarian connective tissue (C). The cell nests diffusely express inhibin (D).

similar immunophenotype to sex cord proliferations in that they may be inhibin-positive and calretininpositive. However, these are morphologically distinct, comprising fascicular and reticular arrangements of foamy cells and lacking microfollicles or luminal spaces containing eosinophilic material.

In three of our cases, the sex cord proliferations were located in the fallopian tube, specifically in the fimbria in two cases. There is an increasing tendency to sample the fallopian tube, especially the fimbria, in risk-reducing salpingectomies and in general, because of the accumulating evidence that this is the site of origin of many or most extrauterine high-grade serous carcinomas. ${ }^{23}$ Given this, it is possible that cases similar to those reported here will be encountered more commonly in the future.

Follow-up is available in four of our cases, ranging from 11 months to 6 years. This has been uneventful in all cases, with no evidence of subsequent tumour development. This supports the hypothesis that the sex cord proliferations described here represent benign non-neoplastic lesions. However, given that AGCTs often recur many years after original surgical removal, we cannot unequivocally, as yet, confirm that the behaviour will be invariably benign.

There may be a clinical dilemma in cases where extraovarian sex cord proliferations such as those reported here are identified and the ovaries are still in situ in a young woman who desires to preserve her fertility. In such cases, there is a theoretical possibility of an undetected ovarian neoplasm, e.g. an AGCT, and it is difficult to exclude this possibility entirely unless bilateral oophorectomy is undertaken. However, if the ovaries are clinically normal in size, we would recommend that imaging be performed, and if no ovarian mass or suspicious lesion 

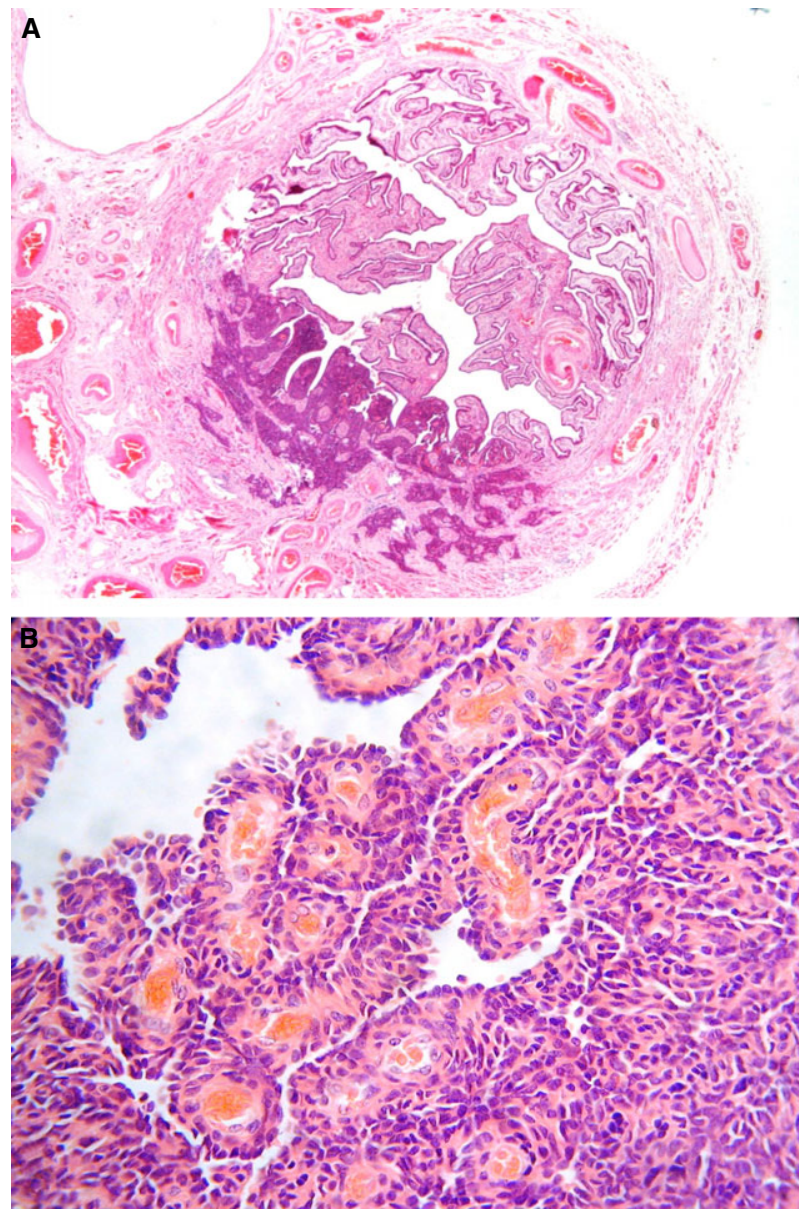

Figure 6. Case 6. Scanning magnification showing a lesion composed of multiple irregular interconnecting nests of cells within the wall of the fallopian tube (A). At high power, the nuclei are ovoid to spindled in shape, and occasional slit-like spaces and a focal pseudopapillary architecture are present (B).

is seen the patient could be followed with regular scans.

In summary, we report a series of cases in which incidentally detected microscopic foci of sex cord cells, which may closely mimic AGCT or SCTAT, were present in extraovarian tissues. We feel that this probably constitutes a benign lesion and a non-neoplastic proliferation of embryonic remnants secondary to abnormal migration. In the pathological reporting of these cases, we recommend stating that the exact significance of the proliferation is uncertain but, in view of the small size, a benign non-neoplastic lesion is favoured rather than a microscopic neoplasm. However, given the uncertain pathogenesis, clinical follow-up with or without appropriate imaging studies and determination of serum inhibin levels are suggested.

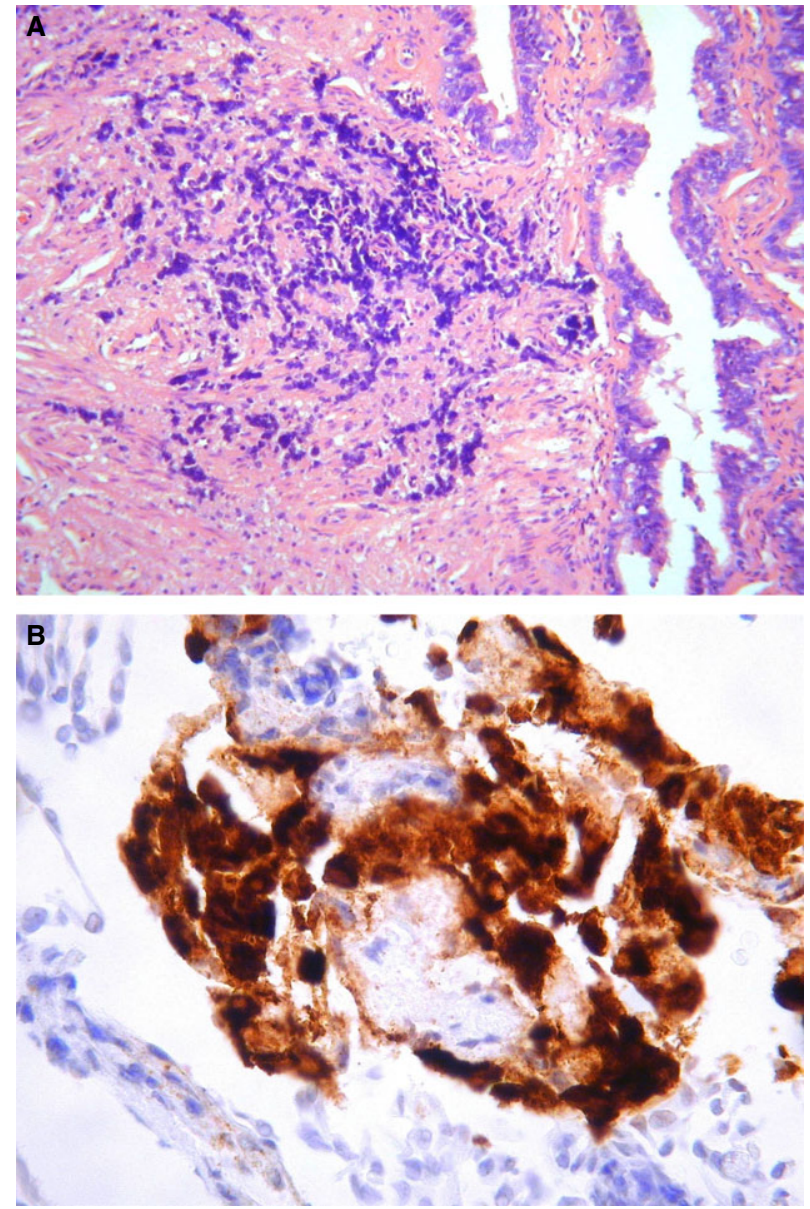

Figure 7. Displaced granulosa cells involving the lamina propria of the fallopian tube. The nuclei are hyperchromatic, and the cells have a crushed appearance (A) and are positive for inhibin (B).

Table 2. Comparison between extraovarian sex cord proliferations and displaced granulosa cells

\begin{tabular}{lll}
\hline & $\begin{array}{l}\text { Sex cord } \\
\text { proliferations }\end{array}$ & $\begin{array}{l}\text { Displaced granulosa } \\
\text { cells }\end{array}$ \\
\hline Age & $\begin{array}{l}\text { Premenopausal or } \\
\text { postmenopausal }\end{array}$ & Premenopausal \\
\hline Nuclei & $\begin{array}{l}\text { Vesicular with or } \\
\text { without grooves }\end{array}$ & $\begin{array}{l}\text { Hyperchromatic, often } \\
\text { crushed }\end{array}$ \\
\hline Architecture & $\begin{array}{l}\text { Diffuse or nested; } \\
\text { microfollicles and } \\
\text { spaces may be } \\
\text { present }\end{array}$ & Diffuse \\
&
\end{tabular}

\section{Acknowledgement}

We would like to thank Dr Blake Gilks (Vancouver, Canada) and the Centre for Translational and Applied 
Genomics (CATG) (Vancouver) for undertaking the FOXL2 mutation analysis in case 2, and Dr Joanne Roche (Royal Glamorgan Hospital, UK) for providing follow-up in case 6 .

\section{Author contributions}

All of the authors provided cases for the study and participated in the writing of the manuscript.

\section{Conflicts of Interest}

There is no conflict of interest for any of the authors.

\section{References}

1. Reddy DB, Rao DB, Sarojini JS. Extra-ovarian granulosa cell tumour. J. Indian Med. Assoc. 1963; 41; 254-257.

2. Gardner GH, Greene RR, Peckham BM. Normal and cystic structures of the broad ligament. Am. J. Obstet. Gynecol. 1948; 55; 917-939.

3. McCluggage WG, Singh N, Kommoss S, Huntsman DG, Gilks CB. Ovarian cellular fibromas lack FOXL2 mutations: a useful diagnostic adjunct in the distinction from diffuse adult granulosa cell tumor. Am. J. Surg. Pathol. 2013; 37; 1450-1455.

4. Vang R, Wheeler JE. Diseases of the fallopian tube and paratubal region. In Kurman RJ, Hedrick Ellenson L, Ronnett BM eds. Blaustein's pathology of the female genital tract. 6th ed. New York: Springer, 2011; 529-578.

5. Lin HH, Chen YP, Lee TY. A hormone-producing thecoma of broad ligament. Acta Obstet. Gynecol. Scand. 1987; 66; 725727.

6. Merino MJ, LiVolsi VA, Trepeta RW. Fibrothecoma of the broad ligament. Diagn. Gynecol. Obstet. 1980; 2; 51-54.

7. Roth LM, Davis MM, Sutton GP. Steroid cell tumor of the broad ligament arising in an accessory ovary. Arch. Pathol. Lab. Med. 1996; 120; 405-409.

8. Sasano H, Sato S, Yajima A, Akama J, Nagura H. Adrenal rest tumor of the broad ligament: case report with immunohistochemical study of steroidogenic enzymes. Pathol. Int. 1997; 47; 493-496.
9. Van Ingen G, Schoemaker J, Baak JA. A testosterone-producing tumour in the mesovarium. Pathol. Res. Pract. 1991; 187; 362-370.

10. Shah SP, Köbel M, Senz J et al. Mutation of FOXL2 in granulosa-cell tumors of the ovary. N. Engl. J. Med. 2009; 25; 2719-2729.

11. Kim T, Sung CO, Song SY, Bae DS, Choi YL. FOXL2 mutation in granulosa-cell tumours of the ovary. Histopathology 2010; 56; 408-410.

12. Jamieson S, Butzow R, Andersson N et al. The FOXL2 C134W mutation is characteristic of adult granulosa cell tumors of the ovary. Mod. Pathol. 2010; 23; 1477-1485.

13. McKenna M, McBride HA, McCluggage WG. CD56 is a sensitive and diagnostically useful immunohistochemical marker of ovarian sex cord-stromal tumors. Int. J. Gynecol. Pathol. 2007; 26; 322-327.

14. Kaku T, Ohiyishi Y, Kobayashi H et al. CD56 expression in ovarian granulosa cell tumors, and its diagnostic utility and pitfalls. Gynecol. Oncol. 2007; 107; 30-38.

15. Hirschowitz L, Salmons N, Ganesan R. Ovarian hilus cell heteropia. Int. J. Gynecol. Pathol. 2011; 30; 46-52.

16. Mason TE, Quagliarello JR. Ectopic pancreas in the fallopian tube. Report of a first case. Obstet. Gynecol. 1976; 48; 70-73.

17. Singh N, Gilks CB, Huntsman DG et al. Adult granulosa cell tumour-like areas occurring in ovarian epithelial neoplasms: report of a case series with investigation of FOXL2 mutation status. Histopathology 2014; 64; 626-632.

18. Clement PB, Young RH, Scully RE. Ovarian granulosa cell proliferations of pregnancy: a report of nine cases. Hum. Pathol. 1988; 19; 657-662.

19. McCluggage WG, Young RH. Non-neoplastic granulosa cells within ovarian vascular channels: a rare potential diagnostic pitfall. J. Clin. Pathol. 2004; 57; 151-154.

20. Vydianath B, Ganesan R, McCluggage WG. Displaced granulosa cells in the fallopian tube mimicking small cell malignancy. J. Clin. Pathol. 2008; 61; 1323-1325.

21. Chui MH, Chapman WB, Clarke BA. Displaced granulosa cells within the ovarian stroma in a BRCA1 mutation carrier. Int. J. Gynecol. Pathol. 2014; 33; 423-424.

22. Duncan DL, Rambally BS, Lininger RA, DiFurio MJ. Displaced granulosa cells in the fallopian tube mistaken for metastatic granulosa cell tumor. Int. J. Gynecol. Pathol. 2013; 32; 35-37.

23. McCluggage WG. Morphological subtypes of ovarian carcinoma: a review with emphasis on new developments and pathogenesis. Pathology 2011; 43; 420-432. 